\title{
Sexual Contact
}

National Cancer Institute

\section{Source}

National Cancer Institute. Sexual Contact. NCI Thesaurus. Code C154689.

Sexual interaction between individuals. 